\title{
A translation with (apparently) no originals
}

\author{
Review: Umberto Eco, Experiences in Translation. \\ (Translated by Alastair McEwen.) \\ Toronto, University of Toronto Press, 2001, x+135 pages.
}

\section{Bruno Osimo ${ }^{1}$}

The genesis of this book about translation itself involves many translation processes. The present volume is based on the Goggio Public Lectures given by Eco at the University of Toronto in 1998. So, one could argue, the prototext of this book was an oral text published (performed) three years before the actual printing. However, the prototext of this book must be also an Italian text, since the book claims to be an English translation. Yet, looking for this book on the Italian publishing market, one sees none — or, better, didn't see any until April 2003.

In April 2003 Eco published a book in Italian, whose title (Dire quasi la stessa cosa. Esperienze di traduzione) is echoed, in part, by the supposed translation's one. Looking into more detail, one discovers that the supposed Italian "original" is 250 pages longer: in fact, in the preface one realizes that the "prototext" of the Italian book consists, in its turn, also of the eight Weidenfeld Lectures given at Oxford in 2002 and two annual seminars for $\mathrm{Ph}$. D. students in semiotics at the Università di Bologna, which explains the greater pagination. I am no longer able to tell if it is an original or not, having been published three years later, with many additions and examples in Italian.

The book is divided in two parts: the first part (Translating and being translated) is devoted to Eco's experiences in translation and supervision of his own texts' translations. In this part I noticed that Eco doesn't have a descriptive approach to translation - prevailing in the modern science preferring rather a normative one. However, this may be not too difficult to explain. I therefore try by abduction to infer that the reason why Eco is often

\footnotetext{
1 Author's address: Bruno Osimo, via Tolentino 19, 20155 Milano, Italy; email: osimo@trad.it; homepage: www.trad.it.
} 
so sure of the validity or censurability of the various translators' choices is that he is the Empirical Author in person. Therefore the intentio operis, usually left to the sometimes perverse, aberrant relation between Model Author and Empirical Reader, here has an indubitable authority - the intentio auctoris - able to tell what is Right and what is Wrong beyond any doubt. Who could tentatively argue in opposition to the will of the Empirical Author, who is both living and writing (novels and semiotics) and translating and writing about translation - who therefore is both metalinguistically and metaculturally self-conscious?

Eco's general approach is along the functionalist school and the skopos theory: he is a promoter of the functional equivalence in interlingual translation, in which he lucidly realizes that the translator must make decisions about the metatext's dominant - although he never uses Jakobson's term: "Obviously this means that translators have to make an interpretative hypothesis about the effect programmed by the original text. Many hypotheses can be made about the same text, so that the decision about the focus of the translation becomes negotiable" (p. 45). In another passage, Eco refers to the dominant as spirit of the text: "[...] rewriting is certainly a case of interpretation, and is translation proper only in part, if not in the sense in which (on the basis of a critical interpretation of the original text) it has pretensions to conveying, not the letter of the original, but its 'guiding spirit' (whatever that means)" (p. 117).

Eco many a time goes round the notion of "dominant" but hardly ever mentions it. In the Italian version an author's footnote explains that the notion of "dominant" is too vague, representing a huge spectrum of features, techniques, arts, functions. However, having rejected this notion as a solution, he proposes to use it as an advice: "search what can be the dominant for you in this text, and on it stake your choices and exclusions".

The Italian semiotician only apparently refuses the possibility that a translator should interpret the text in place of the metatext's reader: "Let us also assume that in an adaptation some levels — deemed fundamental - are isolated, and it is on these levels that we try to 'translate'. But the fact of having isolated some levels means imposing one's own interpretation of the source text" (p. 125; author's italic). That interpretation (and, sometimes, disambiguation) in the translation process is nonetheless implied and, in the Italian version, subject of a whole chapter.

Eco's functional position induces him to discard the translator's footnote hypothesis, as a moment of surrender, of impotence. Speaking of his own Italian translation of Gérard de Nerval's Sylvie, he tells about a potential translation loss solved by the adding of an adverb: "By adding a single 
adverb, I avoided the footnote, which is always a sign of weakness on the part of a translator" (p. 50). This conception implies that the text being translated has as a dominant its fluent readability, which indeed is the case of most Eco's books, both in fiction and in non-fiction. These statements are undoubtedly true for Eco's work, since the author tells us so. And for many works whose dominant lies in the reader's entertainment - both in a narrative and in an intellectual sense. The search for pleasure (almost in a sexual way) in a text is a fortunate topos of Eco's work, as far as both his essays and his novels are concerned.

It would be boring to argue that from a scientific point of view it is not of much use stating norms meant as general rules to be followed, and that from a semiotic point of view there is no kind of message (textual or metatextual, or intertextual for that matter) that is a priori weak; the result must be found out in the empirical readers' reception of the text. Boring and, in the given case, inappropriate, since we are not talking about theory: these are experiences, empirical facts.

In many cases Eco implicitly uses the intersemiotic metaphor, like when he recurs to the simile of the translator as a film director; here he explicitly states his position as far as metatextual or periphrastic rendering is concerned: "But the translator cannot use either images or detailed specifications, and must respect the rhythm of the story, because descriptive longueurs would be fatal" (p. 52). In general, I think that this volume focuses on theoretical boundaries.

This is above all evident in the second essay, "Translation and interpretation". Here Eco starts from where most modern semiotic-oriented translation theories start, i.e. from the celebrated Jakobson's 1959 essay On linguistic aspects of translation. In it Eco tries to set boundaries to the "totalizing" theory of translation (although Torop is never explicitly quoted). My impression is that, as in 1992 with Interpretation and overinterpretation Eco had the sane intention to impose boundaries to the apparently boundariless Deconstructionist approach to literature, allowing any interpretation, included the ones not altogether justified by the text ("aberrant decoding"), so in this 2003 essay his aim is to set boundaries to the apparently boundariless "total translation" approach in which any kind of communication act is assimilable to translation.

However, there might be a misunderstanding on this point. Eco says, for example, that "it would be pure (and not very perspicuous) rhetorical licence to call [the short English description of the Divine Comedy] a translation" (p. 77) of the original. What "totalist" semioticians say, however, is not that all kinds of translations (textual, extratextual, metatextual, intertextual, intra- 
textual) produce a metatext that is the complete rendering of the prototext: what these theorists say is that there is never a complete rendering of a prototext, that any rendering is incomplete. Therefore, it can be useful to study the translation process just because it makes explicit what in interlingual translation is sometimes implicit: the translation choice, as Eco himself states: "In passing into a semiotic system that is totally 'other' with regard to those of the natural languages, the interpreter would have to decide if the 'savants austères' sit in a large and chilly library, in a cramped little room like one of Rembrandt's philosophers, or in front of a lectern like Saint Jerome [...]" (p. 99).

Eco, as always, is very pleasant to read, and this is even more evident in the Italian 2003 version of the essays, containing many more examples. One could say that the Italian version is so rich in examples, that theoretical positions are simply interspersed among them. Through examples he clarifies questions like cultural translatability, archaization/modernization, domestication/estrangement, addition/omission. He is capable of justifying approaches that are hard to be argued, as in cases when the referential content of a text is radically changed in translation, leaving untouched the work intentions. It is a book that, in its Italian version, is a big success, especially among translators, which is a great achievement, since seldom translators are so eager to read about what is sometimes dismissed as "translation theory".

The greatest interest of this book is that it provides a rare chance to see translation simultaneously from the points of view usually associated to three different persons: a translator, a writer, a semiotician. Eco can elegantly manage the three of them. 